Seminário de Pesquisa

Programa de Pós-Graduação

Design FAU USP

\title{
Pesquisa em design sobre recursos vocais de natureza digital para orientação ambiental de pessoas com deficiência visual
}

\author{
Jaldomir da Silva Filho, Denise Dantas
}

mapa; voz; orientação e mobilidade; pessoa com deficiência visual

Apesar de eficientes ferramentas de orientação de pessoas nos espaços públicos, os GPS podem ser inadequados para pessoas com deficiência visual, pois suas interfaces vocais representam simples apoios à sua principal interface, comumente formada por mapas gráficos em pequenas telas de celulares. Este estudo, de caráter qualitativo, busca aprimorar o design de interfaces vocais de GPS para o uso de pessoas com deficiência visual, por meio da coleta de dados de observação da utilização de modelos customizados de audiodescrição para a orientação e mobilidade, possibilitando o plano de estudo que será submetido a conselhos de ética por meio

Curso

Doutorado

Linha de Pesquisa

Design: Processos e Linguagens

\section{Jaldomir da Silva Filho}

Mestre em Ciências pela FAU USP,

Analista de Desenvolvimento

de Sistemas, doutorando a

Universidade de São Paulo.

Profissionalmente, realiza a gestão para a aprovação de sistemas pelo Departamento de Engenharia da Operação do Metrô de São Paulo.

e-mail: jaldomir@usp.br

Lattes: http://lattes.cnpq. br/3016469501518285

Orcid: https://orcid.org/00000002-0634-8775

\section{Denise Dantas}

Docente na Universidade de São Paulo na graduação e pós-graduação em Design, coordenadora do LabDesign FAUUSP e colíder do grupo de pesquisa Design em Ação. Realiza pesquisas em Human Centred Design, Inovação social, Materiais para o design.

e-mail: dedantas@usp.br

Lattes: http://lattes.cnpq. br/7636937300587505

Orcid: https://orcid.org/00000003-4419-6394 da Plataforma Brasil. Durante o levantamento bibliográfico, buscarse-á documentação acadêmica e especializada de origem mundial sobre funcionamento, design e interface de aparelhos eletrônicos para navegação de pessoas com deficiência visual, em acervos de bibliotecas digitais e revistas acadêmicas de universidades como PUC, USP e University of Sydney, assim como em redes e bases de dados acadêmicas como Researchgate, Elsevier e Springer, utilizando-se as palavras-chave "GPS", "map", "guidance", "voice", "blind", “mapa", “orientação", “mobilidade", “voz" e "pessoa com deficiência visual". Ponderando-se os estudos de Sacks (2007), as pesquisas de campo levarão em consideração a experiência reativa de pessoas com deficiência visual ante o uso de interfaces vocais, tratando-se os dados de modo qualitativo, conforme Flick (2009), com base nos processos cognitivos elencados por Rogers, Sharp e Preece (2013). 


\title{
Research on Design about vocal resources of digital nature for environmental guidance of visually impaired people
}

\author{
Jaldomir da Silva Filho, Denise Dantas
}

map; voice; orientation and mobility; visually impaired people

Despite being an efficient tool for orienting people in public spaces, GPS can be unsuitable for people with visual impairments, since its voice interface is a simple support for the main visual interface, commonly constituted by graphic maps on small cell phone screens. This qualitative study seeks to improve the design of vocal GPS interfaces for the use of visually impaired people, through the collection of observation data on the use of customized audio description models for orientation and mobility, enabling a research protocol that will be submitted to the ethics councils through Plataforma Brasil. During the bibliographic survey, academic and specialized documentation of worldwide origin will be sought on the functioning, design and interface of electronic devices for navigation of visually impaired people, in collections of digital libraries and academic journals from universities such as PUC, USP and University of Sydney, as well as in academic networks and databases such as Researchgate, Elsevier and Springer, using the keywords "GPS", "map", “guidance", “voice", "blind", “map", “Orientation", "mobility", "voice" and "visually impaired person". Considering the studies by Sacks (2007), field research will consider the reactive experience of people with visual impairment when using vocal interfaces, treating the data in a qualitative way, according to Flick (2009), based on the processes cognitive factors listed by Rogers, Sharp and Preece (2013).

\section{Jaldomir da Silva Filho}

Master of Science from FAU USP,

Systems Development Analyst, PhD student at the University of São Paulo. Professionally, he manages the systems approval by the Engineering Department Operation of the São Paulo Metro.

e-mail: jaldomir@usp.br

Lattes: http://lattes.cnpq. br/3016469501518285

Orcid: https://orcid.org/00000002-0634-8775

\section{Denise Dantas}

Lecturer for the under and post graduate Design programs at the University of São Paulo, coordinator of LabDesign FAUUSP and co-chair of the research group Design in Action. Active researcher in human centered design, social innovation and materials for design.

e-mail: dedantas@usp.br

Lattes: http://lattes.cnpq. br/7636937300587505

Orcid: https://orcid.org/0000-

0003-4419-6394

\section{Referências | References}

FLICK, U. 2009. Introdução à pesquisa qualitativa. Porto Alegre: Artmed. ROGERS, Y.; SHARP, H. \& PREECE, J. 2013. Design de interação: além da interação homem-computador. Porto Alegre: Bookman.

SACKS, 0. 2007. Alucinações musicais: Relatos sobre a música e o cérebro. São Paulo: Companhia das Letras. 